\title{
Custard apple (Annona squamosa L.) variability in semi- arid region of Gujarat
}

\author{
Vikas Yadav*, Sanjay Singh and V. V. Apparao \\ Central Horticultural Experiment Station (CIAH), Vejalpur, Panchmahals, GODHRA (GUJARAT) INDIA \\ (Email : vikas.yadav15@yahoo.com; vikasyadav.hort@gmail.com)
}

\begin{abstract}
The richness of plant genetic resources and extent of genetic diversity in custard apple provides ample opportunities for improvement in different ways. Wide range of genetic diversity with respect to various aspects of phenology viz., growth, flowering, fruiting behaviour and nutritional and qualitative characters in custard apple offer immense opportunity to explore the germplasm for superior genotypes from existing population growing under Gujarat. Since, genetic diversity is important source of crop improvement for developing promising varieties for livelihood and health security, hence its collection, ex-situ conservation and characterization is necessary under rainfed conditions of semi-arid ecosystem of Gujarat, so as to explored and conserve the source of promising genes for creating better yield, quality and having high medicinal significance and resistance to abiotic stress through selection and hybridization from the different part of Gujarat.
\end{abstract}

Key Words : Biodiversity, Field repository, Health security

View Point Article : Yadav, Vikas, Singh, Sanjay and Apparao, V. V. (2018). Custard apple (Annona squamosa L.) variability in semi-arid region of Gujarat. Internat. J. agric. Sci., 14 (1) : 274-277, DOI:10.15740/HAS/IJAS/14.1/274-277.

Article History : Received : 12.10.2017; Accepted : 30.12 .2017

\footnotetext{
* Author for correspondence:
} 